\title{
SYMPOSIUM ON REVISITING ISRAEL'S SETTLEMENTS
}

\section{THE MISSING ARGUMENT: THE ARTICLE THAT CHANGED THE COURSE OF HISTORY?}

\author{
Eyal Benvenisti*
}

In July 1967, one month after Israel's occupation of the West Bank, Gaza Strip, Sinai Peninsula, and Golan Heights, Israel's Military Advocate General (MAG), Colonel Meir Shamgar, appeared before a Knesset committee to discuss the Israel Defense Forces (IDF)'s duties in the areas under its control. Col. Shamgar had led the MAG Corps in the preparations in the event that a future war would find the army occupying beyond Israel's borders. ${ }^{1}$ Col. Shamgar began his presentation ${ }^{2}$ by stating:

In terms of the legal background, our point of departure is that we have to respect both the fundamental pursuits of the State of Israel as its military forces begin to control an area that has been liberated by the IDF, and the rules of public international law that apply to the actions of any military in control of an area that was, until its entry, subject to the sovereignty of a foreign political entity.

The guiding rules in this realm are the rules of public international law, which are reflected in The Hague Regulations of 1907 ... and in the ... Fourth Geneva Convention on the Protection of Civilians in Times of War.

In line with this approach, on August 11, 1967, Israel's West Bank Military Commander issued the Order Concerning Security Provisions. The Order stipulated (in Article 35) that,

The Military Courts and the Military Courts Administration shall observe the provisions of the Geneva Convention of August 121949 Relative to the Protection of Civilian Persons in Time of War in any matter connected with judicial proceedings. In any contradiction between this Order and the said Convention, the provisions of the Convention shall prevail.

However, as Beni Rubin notes, " "[] change of heart was based on an article published by Yehuda Blum."

* Whewell Professor of International Law at the University of Cambridge. Thanks to Beni Rubin and Eliav Lieblich for their comments and to Yuval Spitzer for research assistance.

${ }^{1}$ Meir Shamgar, Legal Concepts and Problems of the Israeli Military Government- The Initial Stage, in MilitARy GovernMENT IN THE TERRITORIES Administered by Israel, 1967-1980: The Legal Aspects 1, 13 (Meir Shamgar ed., 1982); David Kretzmer, The Occupation of Justice 32 (2002).

2 Transcript No. 126 of the Constitution, Law and Justice Committee session (July 5, 1967).

${ }^{3}$ Benjamin Rubin, Israel, Occupied Territories, in Max Planck Encyclopedia of Public International Law (Rüdiger Wolfrum ed., 2009$)$. Kretzmer also attributes the change of heart to Blum's article (Kretzmer, supra note 1, at 33).

\footnotetext{
The American Society of International Law and Eyal Benvenisti (C) 2017. This is an Open Access article, distributed under the terms of the Creative Commons Attribution licence (http://creativecommons.org/licenses/by/4.0/), which permits unrestricted re-use, distribution, and reproduction in any medium, provided the original work is properly cited.
} 
The article, "The Missing Reversioner: Reflections on the Status of Judea and Samaria," was written by a young Lecturer at the Hebrew University of Jerusalem and published in the Faculty of Law's English version law journal. ${ }^{4}$ In 1971, now the Israeli Attorney General, Meir Shamgar elaborated on what would become Israel's official position. Shamgar began his essay by warning himself and his audience against "the great difficulty in approaching problems connected with the actual implementation of the rules of warfare without influence by innate prejudices or deep-seated subjective outlook." 5 But the view he offered might not have been devoid of the same concerns. Arguing that the West Bank (or in his words, "Judea and Samaria") and Gaza were not occupied territories, Shamgar invoked the said article by Blum, and concluded that " $[$ t] he territorial position [of the West Bank and Gaza] is thus sui generis ... and the Israeli government tried therefore to distinguish between theoretical juridical and judicial problems ... and the observance of the humanitarian provisions of the Fourth Geneva Convention."

The same conclusion applied, in Shamgar's view, to the applicability of the Hague Regulations. ${ }^{7}$

Shamgar incorporated Blum's slender but tantalizing thesis almost in its entirety into his essay. In fact, nested within a twenty-three-page article, Blum's argument was merely one paragraph long. ${ }^{8}$ Blum presented his provocative thesis as if it were self-evident, and perhaps therefore not worthy of extended and rigorous examination.

The article, ostensibly devoted to an examination of the lawfulness of a military order under the law of occupation, actually explored a preliminary question - whether Jordan had valid title to the West Bank (referred to as "Judea and Samaria"). Concluding that Jordan had no title, Blum continued effortlessly to find, "clear[ly] from the preceding discussion," that the law of occupation did not apply. Blum stipulated that there were two conditions (which he called "assumptions") for the applicability of the laws of occupation-the existence of "reversionary rights" of the ousted legitimate government to the territory in question, and the occupier's lack of territorial claims over the area under its control. Having refuted the first condition in his preliminary assessment of Jordan's title, he concluded that "those rules of belligerent occupation directed to safeguarding that sovereign's reversionary rights ha[d] no application"" to Israel's control of the West Bank and, for similar reasons, also to Gaza.

In a long footnote, Blum alludes to the "far-reaching implications" of his conclusion, namely that "[s]ince in the present view no State can make out a legal claim that is equal to that of Israel, this relative superiority of Israel may be sufficient, under international law, to make Israel possession of Judea and Samaria virtually indistinguishable from an absolute title, to be valid erga omnes." 10 This argument implies that the occupier can evade its responsibilities by unilaterally asserting its relative superior title to that of the ousted government. This view undercuts the purpose of the law of occupation, namely to preserve the legal status quo until an agreement is reached.

While Blum acknowledged that the part of the law of occupation "which is intended to safeguard the humanitarian rights of the population" did apply, ${ }^{11}$ he failed to identify the scope of those "humanitarian rights." In a footnote, Blum refers to Article 47 of the Fourth Geneva Convention to prove the "severability of the rules of a humanitarian nature from those protecting the ousted sovereign's reversion," 12 but Article 47 is not about the severability of rights and duties; just the opposite. Indeed, the whole point of Article 47 is to insist on the

\footnotetext{
${ }^{4}$ Yehuda Z. Blum, The Missing Reversioner: Reflections on the Status of Judea and Samaria, 3 IsR. L. Rev. 279 (1968).

${ }^{5}$ Meir Shamgar, The Observance of International Law in the Administered Territories, 1 IsR. Y.B. Hum. RigHTS 262 (1971).

${ }^{6} I d$. at 266.

${ }^{7} I d$. at 266.

${ }^{8}$ Blum, supra note 4 , at 293.

${ }^{9}$ Id.

${ }^{10} \mathrm{Id}$. at note 60

${ }^{11}$ Id. at 294.

${ }^{12} \underline{I d}$. at 294 , note 59 .
} 
nonseverability of protection, ensuring that " $[\mathrm{p}]$ rotected persons who are in occupied territory shall not be deprived, in any case or in any manner whatsoever, of the benefits of the [Fourth] Convention." 13 There are no qualifications: all the benefits, in all circumstances: even if the occupier introduces changes "into the institutions or government of the said territory" or even annexes it. ${ }^{14}$ This reading is fully consonant with the raison d'etre of the Fourth Geneva Convention which, as its title suggests, is about the protection of civilian persons in time of war (and not the protection of their ousted government). The Fourth Geneva Convention is all about, and only about, "humanitarian rights," and the lack of a "lawful reversioner" is beside the point.

The ramifications of the ostensible distinction between the humanitarian rights of the population and the rights of the lawful sovereign would become clear only a decade later. Then, under a Likud government, Israel contended that Article 49 of the Fourth Convention, which prohibited the transfer of the occupier's own civilians to occupied territories, was "intended to protect the rights of the "legitimate sovereign'," hence "[did] not apply in respect of Jordan," and therefore did not prohibit Jewish settlements. ${ }^{15}$ Blum, now the Israeli Ambassador to the United Nations, asserted during a Security Council debate on March 13, 1979 that "[w]e do not regard ourselves as foreigners in those areas. The Israeli villages in Judaea, Samaria and the Gaza District are there as of right and are there to stay." 16 Blum sought to assure the audience that "no Arab inhabitants have been displaced by the establishment of the villages in question." 17

To support Blum's thesis, his article refers only to one authority, Gerhard von Glahn's treatise, The Occupation of Enemy Territory..$^{18}$ But the reference hardly supports Blum's conclusion. Blum draws on von Glahn's use of the term to "the sovereign, the legitimate government of the occupied territory" and seeks to draw from it that the ousted government must have a valid title over the area to be "legitimate." But this was not von Glahn's view at all. Throughout his book, von Glahn refers to "the legitimate government" or "the legitimate sovereign" to distinguish it from the occupier (von Glahn was obviously relying on the text of Article 43 of the Hague Regulation ${ }^{19}$ that refers to " $t$ ] he authority of the legitimate power" to emphasize that the passing of that authority "in face" to the occupier does not assign to the latter any legal title). Von Glahn never recognizes an occupation of a territory, to which title is disputed, as a distinct type of occupation. ${ }^{20}$

The quote from von Glahn's book that Blum relies upon is taken out of a special chapter devoted to "The Legal Status of Defeated Germany." In this chapter, von Glahn singles out the unique situation of Germany after its unconditional surrender in 1945. Von Glahn does not discuss relative claims to title but an entirely different matter: the situation of debellatio, when the ousted government ceases to exist. In other words, von Glahn's quote was taken out of its context.

What for von Glahn is a unique and "most perplexing legal controversy" that merits a separate chapter becomes for Blum the one example to support his thesis. What for von Glahn were "[f]our major schools of thought

${ }^{13}$ Geneva Convention relative to the Protection of Civilian Persons in Time of War art. 47, Aug. 12, 1949, 75 UNTS 287.

${ }^{14} \underline{I d}$.

${ }^{15}$ Israeli Ambassador to the UN Chaim Herzog before the General Assembly of the United Nations on October 26, 1979, cited in Nissim Bar-Yaacov, The Applicability of the Laws of War to Judea and Samaria (The West Bank) and to the Gaza Strip Israel Law, 24 Isr. L. Rev. 485, 488 (1990).

${ }^{16}$ UN SCOR (Provisional), 34th Sess., 2125th mtg. at 36, UN Doc. S/PV.2125 (Mar. 13, 1979).

${ }^{17}$ UN SCOR, 34th Sess., 2131st mtg. at 11, UN Doc. S/PV.2131 (Mar. 19, 1979).

18 Gerhard von Glahn, The Occupation of Enemy Territory (1957).

19 Article 43: "The authority of the legitimate power having in fact passed into the hands of the occupant, the latter shall take all the measures in his power to restore, and ensure, as far as possible, public order and safety, while respecting, unless absolutely prevented, the laws in force in the country."

${ }^{20}$ Von GLAHN, supra note 18, at 27, where he discusses various types of occupations. 
[which] have developed among the numerous writers who have speculated on the legal status of post-surrender Germany" 21 becomes for Blum-who relies again only on von Glahn on this point- "a considerable number of authors [who] have taken the view that when the last Government of the Third Reich ... was dissolved ... the Hague Regulations as such ceased to apply to that situation, since German sovereignty ceased to exist."22

It turns out, however, that the argument that Germany had ceased to exist at the end of the war, while supported by an impressive line of authorities, was not beyond serious dispute. While the Allies' title to Germany was not challenged, its seemingly logical consequence, namely the inapplicability of the law of occupation to the administration of the territory, was convincingly contested, especially by German scholars. ${ }^{23}$ They emphasized the predicament of the population under what actually was alien domination. Formal legal principles aside, they argued, international law must not abandon its concern for the local population only because the national institutions had disappeared. Max Huber, a towering figure in international law and the then president of the International Committee of the Red Cross, voiced his discomfort with the Allied legal claim in a letter to U.S. Secretary of State James F. Byrnes:

Unconditional surrender of the German and Japanese forces which resulted in their laying down arms without the special reservations usually inserted in armistice conventions, does not ipso facto imply that the capitulating power abandons all claim to the benefits of the Hague and Geneva Conventions in favor of its nationals. ${ }^{24}$

The drafters of the Fourth Geneva Convention sought in 1949 to clarify the scope of protection of inhabitants in occupied territories. They did so in Article 2 of the convention. As von Glahn points out, this article "represents a definite and, in the opinion of this writer, successful attempt to void some of the shortcomings of the Hague conventions and Regulations." ${ }^{25}$ Blum does not refer to von Glahn on this point, nor does he even mention Article 2. But this Article is pertinent as it stipulates that

the present Convention shall apply to all cases of declared war or of any other armed conflict which may arise between two or more of the High Contracting Parties, even if the state of war is not recognized by one of them. The Convention shall also apply to all cases of partial or total occupation of the territory of a High Contracting Party, even if the said occupation meets with no armed resistance.

The famous debate about Israel's narrow interpretation of Article 2 in regard to the West bank and Gaza (namely whether the reference to "the territory of a High Contracting Party" signifies a condition that the ousted government must have valid title over the territory) did not begin with Blum's article. This claim was elaborated for the first time more than a decade later by Shamgar, by now the Deputy President of the Israeli Supreme Court, soon to become its President. ${ }^{26}$

Blum's argument reflects the understanding in the early days of the crystallization of the concept of occupation, when the occupation regime was designed as a "pact between state elites, promising reciprocal guarantees of political continuity." 27 In those days, the complete subjugation of territory might assign title to the conqueror (based on

${ }^{21} I d$. at 276.

22 Blum, supra note 4, at 293.

23 Eyal Benvenisti, The International Law of Occupation 162 (2d ed., 2012).

${ }^{24} I d$. at 163 .

${ }^{25}$ VON GLAHN, supra note 18, at 20.

${ }^{26}$ Shamgar, supra note 1 , at 34 .

${ }^{27}$ Benvenisti, supra note 23 , at 71 . 
the doctrine of debbelatio). But even such early understanding of the regime would eschew the view that a claim for a relative better title could undermine the temporary measure that the concept of occupation was designed to provide.

But Blum's article was written in 1967, long after the claim of debbelatio was rejected in the context of World War II occupations (the recognition of governments in exile, the status of Germany and Japan) and long after it was laid to rest by Article 2 of the Fourth Geneva Convention. ${ }^{28}$ By 1967, the right of peoples to self-determination had gained the status of a legal right, and human rights of individuals have been inscribed in solemn declarations and covenants. During that period, the ousting of a government could no longer divest the inhabitants of an occupied area of their entitlement.

Was Blum's article an exercise in what some today would call "lawfare" or a serious effort to approach the problem "without influence by innate prejudices or deep-seated subjective outlook"? All one can conclude from revisiting Blum's text is that it offered less than a serious effort to elucidate the legal questions. His brief argumentation leaves out too much to enable an informed assessment of the underlying claim. Did the article influence Israeli decisionmakers or has it served as an apology for their preferred agenda? It would be distressing to think that indeed it was this article that was responsible for the legal about-face in 1967.

28 Benvenisti, supra note 23, at 161-164. 